\title{
Influence of Meat Processing on the Content of Organochlorine Pesticides
}

\author{
Muresan $\mathbf{C}^{1 *}$, Covaci $\mathbf{A}^{2}$, Socaci $\mathbf{S}^{1}$, Suharoschi $\mathbf{R}^{1}$, Tofana $\mathbf{M}^{1}$, Muste $\mathbf{S}^{1}$ and Pop $\mathbf{A}^{1}$
}

${ }^{1}$ Faculty of Food Science and Technology, University of Agricultural Sciences and Veterinary Medicine, Cluj-Napoca, Romania

${ }^{2}$ Toxicological Center, University of Antwerp, Universitetsplein, Wilrijk B-2610, Belgium

\begin{abstract}
The purpose of this study was to identify pathways to reduce Organochlorine pesticides (OCP) contamination, through various thermal methods used for meat processing and to establish mathematic models predictive for the influence of thermal treatments on the OCP residues content in meat. By cold smoking, a reduction of less than $1 \%$ in the OCP content was observed, while for frying, the reduction was up to $48 \%$. Warm smoking and pasteurization as combined treatments, determined as well a reduction in the OCP content of maximum 15 and $16 \%$, respectively. Baking reduced also the level of OCPs with a maximum of $56 \%$. Stewing under pressure caused the most dramatic reduction in the OCP levels (up to 92\%). Using the Mc Donald's polynomial regression, predictive mathematical models for the variation of OCP levels with the applied heat treatments were computed. These models allow a good selection of the appropriate industrial food processing with the ultimate goal to reduce OCP residues.
\end{abstract}

Keywords: OCPs; Meat; Thermal processing; Predictive mathematical models

\section{Introduction}

Organochlorine pesticides (OCPs) were widely used worldwide until restrictions were introduced in the late 1970s. However, despite these measures, OCPs are still among the most prevalent environmental pollutants and are present in food for human consumption [1]. They are mainly found in lipid-rich food of animal origin, such as meat, fish and dairy products, which constitute an important part of our daily diet. It has been suggested that food of animal origin is responsible for more than $90 \%$ of the average human intake of polychlorinated biphenyls PCBs and OCPs [2]. One common feature of OCPs is that they bio-accumulate in the food chain and in the human body, and, as a consequence, represent a potential risk for the human health $[3,4]$. Therefore, it is important to reduce levels of OCPs in food of animal origin. Studies on the influence of thermal processing of foods contaminated with OCP residues have showed this treatment as being the determining factor for their significant decrease through food processing [5-11]. Thus, thermal treatments, such as frying, baking, grilled, boiling and microwave cooking were the best options to reduce the pesticide load in raw meat [12-17].

Recent research on this topic has mainly focused on several pollutants, such as arsenic, polychlorinated dibenzo-p-dioxins and dibenzofurans (PCDD/Fs), polychlorinated biphenyls (PCBs), hexachlorobenzene (HCB), polycyclic aromatic hydrocarbons (PAHs), polychlorinated diphenyl ethers (PCDEs), and polybrominated diphenyl ethers (PBDEs), in several fish and meat food products $[7,12,15,18,19]$. The reduction in the content of pollutant residues through processing of food products is due to the variable lipid content of the analyzed foodstuffs, as well as to the variation in the lipid content in samples of the same food item. However, taking into account that PCDD/Fs, PCBs, PBDEs, PCDEs, and other organic pollutants are associated with the fat portion of foods, cooking methods that release or remove fat from the product will tend to reduce the total amount in the cooked food. Results showed that the influence of cooking on the levels of these contaminants depends not only on the particular cooking process, but even more on the specific food item [7]. Dietary exposure to these environmental pollutants can be thus reduced by discarding the fat, which is released from foods during cooking. The purpose of meat thermal treatment is to improve its hygienic and flavour qualities. Therefore, the present study aimed to build a prediction model on the influence of thermal treatments in order to reduce the meat content of OCPs. Based on the obtained experimental results and using Mc. Donald's polynomial regression, predictive mathematical models were computed for the dependency of OCP levels in meat with the applied heat treatments.

\section{Materials and Methods}

\section{Samples collection, storage and processing}

The material for analysis consisted of pork neck meat and was sampled from one commercial unit in Cluj-Napoca (Romania). A number of 18 pork neck meat samples were injected in several places with a mixture of OCPs using a $15 \%$ saline solution containing the contaminants in a concentration of $200 \mathrm{ng} / \mathrm{g}$ fat. The fortified samples were kept for six days at a temperature of $0-4^{\circ} \mathrm{C}$. The control $(6$ meat samples) and fortified samples were subjected to six different thermal treatments. The working parameters for the thermal treatments are presented in Table 1.

\section{Chemicals and materials}

An OCP standard mixture containing: aldrin, $\alpha$-chlordane,

\begin{tabular}{|c|c|c|c|}
\hline Processing operation & Code & Temperature $\left({ }^{\circ} \mathbf{C}\right)$ & Time \\
\hline Cold smoking & AFR & 45 & $3 \mathrm{~h}$ \\
\hline Warm smoking & AFC & 85 & $1 \mathrm{~h}$ \\
\hline Pasteurization & PST & 74 & $2 \mathrm{~h}$ \\
\hline Frying & FR & 180 & $10 \mathrm{~min}$ \\
\hline Baking & CO & 110 & $1 \mathrm{~h}$ \\
\hline Stewing under pressure (cooking) & IN & 130 & $1 \mathrm{~h}$ \\
\hline
\end{tabular}

Table 1: Processing operations codes and working parameters for thermal treatments.

*Corresonding author: Muresan C, Faculty of Food Science and Technology, University of Agricultural Sciences and Veterinary Medicine, Cluj -Napoca, Romania, Tel: 0728104321; E-mail: crina.muresan@usamvcluj.ro

Received October 15, 2015; Accepted November 15, 2015; Published November 15,2015

Citation: Muresan C, Covaci A, Socaci S, Suharoschi R, Tofana M, et al. (2015) Influence of Meat Processing on the Content of Organochlorine Pesticides. J Food Process Technol 6: 517. doi:10.4172/2157-7110.1000517

Copyright: (c) 2015 Muresan C, et al. This is an open-access article distributed under the terms of the Creative Commons Attribution License, which permits unrestricted use, distribution, and reproduction in any medium, provided the original author and source are credited. 
$\gamma$-chlordane, 4,4'-DDD, 4,4'-DDE, 4,4'-DDT, dieldrin, endosulfan I, endosulfan II, endosulfan sulfate, endrin, endrin aldehyde, endrin ketone, heptachlor, heptachlor epoxide and methoxychlor (Restek Corp, SUA) was used to construct the calibration curves. A stock mixture of OCP standards in hexane was prepared and stored at $4^{\circ} \mathrm{C}$. The calibration curve of each OCP wa s constructed using standard samples with six different concentrations $(5,10,50,100,200$ and 500 $\mathrm{ng} / \mathrm{g}$ ) of the standard mixture solution.

The areas of the obtained peaks were plotted as function of the concentration. Each sample and standard solution was analyzed in duplicate using GC-ECD. The method was validated by determining recoveries, correlation coeficients, relative standard deviations (RSD) and detection limits (Table 2). The precision of the method was satisfactory with RSDs $<20 \%$ for all OCPs.

\section{Fat extraction by automatic extractor}

A Soxhlet apparatus (VELP Scientifica) was used for the determination of the fat content in the meat samples. Ten gm of meat were accurately weighed and homogenized with $10 \mathrm{~g}$ of Celite. The mixture was quantitatively transferred into an extraction thimble. Before use, the extraction thimble was washed with $15 \mathrm{~mL}$ of acetone and $15 \mathrm{~mL}$ of hexane. Fat extraction was performed by Soxhlet extraction with $90 \mathrm{~mL}$ of petroleum ether at $70^{\circ} \mathrm{C}$ by placing the extractor slider into the "immersion" position for $10 \mathrm{~min}$ and, successive ly, into the "washing" position for $180 \mathrm{~min}$.

\section{Cryogenic extraction of pesticides}

In order to measure the fat content, $0.5 \mathrm{~g}$ of fat was weighted and mixed with $3 \mathrm{~mL}$ of methylene chloride-acetonitrile mixture (25:75, $\mathrm{v} / \mathrm{v})$. The mixture was centrifuged at $3000 \mathrm{rpm}$ at $-15^{\circ} \mathrm{C}$ for $20 \mathrm{~min}$. The supernatant layer was transferred into a different tube and slowly heated in a water bath at $40^{\circ} \mathrm{C}$ to melt the fat. The extraction was re peated with another $3 \mathrm{~mL}$ of acetonitrile- methylene chloride mixture and centrifugation was repeated. Second supernatant layer was added to the first one. The organic phase was evaporated at $35^{\circ} \mathrm{C}$ under a nitrogen stream in order to reach a final volume of 2 to $3 \mathrm{ml}$ (solution A).

\section{Partitioning on C18 SPE cartridge}

A SPE vacuum manifold, SPE Florisil cartriges $(6 \mathrm{~mL}, 2000 \mathrm{mg})$ and SPE Chromabond C18 cartridges $(6 \mathrm{~mL}, 500 \mathrm{mg})$ were used for the

\begin{tabular}{|l|c|c|c|c|}
\hline Compounds & $\begin{array}{c}\text { Mean recovery } \\
\mathbf{( \pm ~ S D )}\end{array}$ & $\begin{array}{c}\text { Correlation } \\
\text { Coefficient (R2) }\end{array}$ & RSD \% & $\begin{array}{c}\text { Detection } \\
\text { limits (ng/g) }\end{array}$ \\
\hline heptachlor & $97.4 \pm 1.0$ & 0.9998 & 10.6 & 1 \\
\hline aldrin & $70.6 \pm 8.4$ & 0.9999 & 13.1 & 1 \\
\hline heptachlor epoxide & $83.5 \pm 1.1$ & 0.9997 & 7.0 & 5 \\
\hline Y chlordane & $77.7 \pm 9.3$ & 0.9998 & 12.9 & 5 \\
\hline a chlordane & $73.6 \pm 1.1$ & 0.9996 & 10.4 & 5 \\
\hline 4.4 DDE & $70.5 \pm 9.3$ & 0.9996 & 12.3 & 5 \\
\hline endosulfan I & $77.2 \pm 9.2$ & 0.9999 & 10.3 & 1 \\
\hline dieldrin & $67.9 \pm 1.2$ & 0.9993 & 10.4 & 1 \\
\hline endrin & $100.6 \pm 1.6$ & 0.9999 & 10.5 & 1 \\
\hline 4.4 DDD & $74.2 \pm 1.2$ & 0.9996 & 6.9 & 1 \\
\hline endosulfan II & $67.9 \pm 1.5$ & 0.9997 & 11.9 & 1 \\
\hline 4.4 DDT & $83.2 \pm 1.2$ & 0.9991 & 10.6 & 1 \\
\hline endrin aldehyde & $77.7 \pm 1.5$ & 0.9993 & 15.3 & 1 \\
\hline methoxychlor & $102.5 \pm 1.1$ & 0.9997 & 15.9 & 1 \\
\hline endosulfan sulfate & $111.0 \pm 1.2$ & 0.9992 & 11.8 & 1 \\
\hline endrin ketone & $77.2 \pm 2.7$ & 0.9994 & 10.9 & 1 \\
\hline
\end{tabular}

Table 2: Mean recoveries, correlation coefficients, relative standard deviation (RSD\%) and detection limits. purification of the obtained extracts. The $\mathrm{C} 18$ cartridge was activated by eluting twice with $5 \mathrm{ml}$ of petroleum ether, then $5 \mathrm{ml}$ of acetone and finally $5 \mathrm{ml}$ of methanol. Eluted solutions were discarded. The solution A was added in cartridge and left for $3 \mathrm{~min}$, then eluted with $10 \mathrm{~mL}$ acetonitrile at a flow rate of one drop per every three seconds. The eluted solution was collected in a suitable container. The collected eluant was concentrated on a rotary evaporator and dissolved in $5 \mathrm{ml}$ n-hexane (solution B).

\section{Clean-up by Florisil SPE cartridge}

Florisil SPE cartridge was conditioned by elution with $10 \mathrm{ml}$ of $\mathrm{n}$-hexane. Solution B was added in the cartridge and left for $3 \mathrm{~min}$, and then was eluted with $10 \mathrm{~mL}$ of ethyl ether-petroleum ether (98:2) with a flow rate of one drop per second, for all OCPs, except endrin and dieldrin. The eluted fraction was collected in an evaporation flask. For endrin and dieldrin, the Florisil SPE cartridge was further eluted with $12 \mathrm{ml}$ of petroleum ether-diethyl ether (85:15) with a flow rate of one drop per every three seconds. The second fraction was collected in the same flask as the first part. Finally, the elution mixture was brought to dryness and redissolved in $5 \mathrm{ml}$ hexane.

\section{Analysis}

The purified extracts were analyzed using a Shimadzu 2010 Gas Chromatograph (GC) equipped with an electron capture detector (ECD). The column temperature started at $150^{\circ} \mathrm{C}$ for $2 \mathrm{~min}$, The raised to $200^{\circ} \mathrm{C}$ at $4^{\circ} \mathrm{C} / \mathrm{min}$, kept at $200^{\circ} \mathrm{C}$ for $5 \mathrm{~min}$, raised to $230^{\circ} \mathrm{C}$ at $5^{\circ} \mathrm{C} /$ min, kept at $230^{\circ} \mathrm{C}$ for $5 \mathrm{~min}$, raised to $300^{\circ} \mathrm{C}$ at $2^{\circ} \mathrm{C} / \mathrm{min}$, and then kept at $300^{\circ} \mathrm{C}$ for $5 \mathrm{~min}$. The temperatures of injector and detector were $250^{\circ} \mathrm{C}$ and $315^{\circ} \mathrm{C}$, re spectively. The injection volume was $1 \mu \mathrm{L}$. The flow rates of the carrier gas ( $\mathrm{He}$ ) and make up gas (N2) were maintained at 19.2 and $3.0 \mathrm{~mL} / \mathrm{min}$, respectively. A Restek capillary column (RTx$5,20 \mathrm{~m}$ length and internal diameter of $0.18 \mathrm{~mm}$, with $0.4 \mu \mathrm{m}$ film thickness) was used for the separation of OCPs.

\section{Statistical analysis}

The statistical analysis was achieved with GraphPad Prism v5.00 (Graph Pad, San Diego, CA, USA). Analysis of variance (one-way Anova) was used to compare the level of each OCP between the thermal treatments. The predictive mathematical model used to assess the influence of the various thermal treatments on the reduction of OCP contents in the fortified samples was established using the Mc Donald's polynominal regression.

\section{Results and Discussion}

\section{Organochlorine pesticide residues determination in the control sample}

For each thermal treatment (AFR, AFC, PST, FR, CO, IN), a control sample was used. Table 3 presents the results obtained for the OCP residues ( $\mathrm{ng} / \mathrm{g}$ fat) in the control sample. It can be observed that the control pork meat sample contained DDT, DDE and DDD residues at $33.8 \mathrm{ng} / \mathrm{g}$ fat, a value which falls under the maximum residual limit (MRL, $\Sigma$ DDTs $1000 \mathrm{ng} / \mathrm{g}$ ). Covaci reported residues of OCPs in organs and fat tissue from Romanian pigs over the MRL, while the pork samples analyzed by Covaci had OCP concentrations under the MRL.

\section{Head treatments efficiency applied to reduce Organochlorine pesticides level in fortified pork neck samples}

After fortification at a concentration of $200 \mathrm{ng} / \mathrm{g}$ fat, the pork meat samples were subjected to the thermal treatments presented in Table 1. 
As a consequence of applied heat treatments to pork neck samples, variations from control samples in the levels of OCPs were observed (Table 4). A reduction of only $1 \%$ in the OCP content from control sample was observed after cold smoking (AFR). Warm smoking (AFC) and pasteurization (PST) as combined treatments determined a higher reduction in the OCP contents from control sample of up to 15 and $16 \%$, respectively. Both frying (FR) and baking (CO) led to an even higher reduction in the OCP content of up to 46 and 56\%, respectively. Stewing under pressure and cooking caused the most dramatic decrease in the OCP levels up to $92 \%$. The above mentioned tendencies refer to the reduction of the degree of contamination from one treatment to another, making possible a hierarchy for the decontamination processes, from less efficient to most efficient. Thus, the contamination reduction ratios vary in the following order:

$$
\mathrm{AFR}<\mathrm{AFC}+\mathrm{PST}<\mathrm{PST}+\mathrm{AFC}<\mathrm{FR}<\mathrm{CO}<\mathrm{IN}
$$

\begin{tabular}{|l|c|c|}
\hline Organoclilorine pesticide & Measured (ng/g fat) & MRL (ng/g fat) \\
\hline aldrin+dieldrin & ND & 200 \\
\hline endrin & ND & 50 \\
\hline endrin ketone & ND & n.s. \\
\hline$\Sigma$ „drins” & ND & \\
\hline$\alpha$ chlordane & ND & 50 \\
\hline$y$ chlordane & ND & n.s. \\
\hline$\Sigma$ chlordanes & ND & \\
\hline $4,4^{\prime}-$ DDT & 7.9 & \\
\hline $4,4 '-D D E$ & 23 & \\
\hline $4,4 '-D D D$ & 2.9 & 1000 \\
\hline$\Sigma$ DDTs & 33.8 & 200 \\
\hline heptachlor & ND & 200 \\
\hline heptachlor epoxide & ND & \\
\hline$\Sigma$ heptachlors & ND & 50 \\
\hline endosulfan I & ND & 50 \\
\hline endosulfan II & ND & \\
\hline$\Sigma$ endosulfans & ND & 10 \\
\hline methoxychlor & ND & \\
\hline
\end{tabular}

ND-not detected; n.s-not specified:

Table 3: Organochlorine pesticide levels (ng/g fat) in the control sample, a commercially available pork neck, lipid content $23.5 \%$. Levels are compared against the Maximum Residue Levels (MRLs) set in the European legislation [27].
The main cause in the reduction of the OCP content was the loss of fat during treatments and, only in to a smaller extent, the reduction was due to chemical transformations that are taking place. Heat treatments were effective, since they reduced the OCP content of the meat, as noted in other studies $[5,6,8,20,21]$.

Zabic et al., determined the levels of $\mathrm{HCB}$ in raw skinless Chinook salmon and carp fillet sampled from the Great Lakes. HCB concentrations were also measured after baking, charbroiling, and canning salmon, as well as after pan and deep fat frying carp. The cooking procedures significantly reduced $\mathrm{HCB}$ content (with more than $40 \%$ ) and only few significant differences were found among the various cooking methods.

In another study, cooking processes were further tested to assess their potential to reduce the levels of $\mathrm{HCB}$ and other pesticides in fish. Lean skinless lake trout and siscowets (fat laketrout) from the Great Lakes were cooked by baking and charbroiling. In all cases, cooking reduced the levels of HCB in comparison to the raw samples (17.5\% in baked and $19.5 \%$ in charbroiled samples, respectively). Bayen examined the effects of various cooking processes on the potential loss of various POPs, including PBDEs, from salmon. Losses of PBDEs as the result of the cooking processes, and without skin removed, were the following: $42 \%, 25 \%, 32 \%$ and $44 \%$ for pan- frying, microwave cooking, boiling and baking, respectively. The authors concluded that the reduction of POP burden (including PBDEs) in cooked fish would be a result of efficient lipid removal during the cooking process rather than by the type of cooking method used.

The statistical analysis of obtained data showed significant correlations between pairs extremely comparable for all treatments except stewing under pressure (cooking), where the correlation is insignificant (Table 4).

\section{Organochlorine pesticides weight variability during applied heat treatments}

The evolution of OCP contribution in the fortified meat samples after the thermal treatments is presented in Figure 1. For heptachlor, its share increased after frying (5.22\%) and baking (5.36\%) compared

\begin{tabular}{|c|c|c|c|c|c|c|c|}
\hline \multirow[t]{2}{*}{ Organochlorine pesticides } & \multicolumn{7}{|c|}{$\%$ from $M$} \\
\hline & M & AFR & AFC+PST & PST+AFC & FR & CO & IN \\
\hline heptachlor & 100.0 & 99.8 & 89.8 & 88.1 & 68.6 & 55.9 & 11.8 \\
\hline aldrin & 100.0 & 99.3 & 86.9 & 84.8 & 64.3 & 52.4 & 10.6 \\
\hline Heptachlor epoxide & 100.0 & 99.0 & 88.9 & 88.0 & 67.6 & 51.8 & 18 \\
\hline y chlordane & 100.0 & 99.2 & 85.4 & 84.6 & 63.9 & 45.3 & 18.6 \\
\hline 4.4'DDE & 100.0 & 99.0 & 88.0 & 85.4 & 54.6 & 47.8 & 7.6 \\
\hline endosulfan I & 100.0 & 99.2 & 86.0 & 84.6 & 63.7 & 43.4 & 15.9 \\
\hline dieldrin & 100.0 & 99.4 & 89.3 & 84.7 & 64.5 & 53.7 & 10.7 \\
\hline 4.4'DDD & 100.0 & 99.1 & 88.3 & 85.8 & 54.7 & 48.2 & 9.2 \\
\hline endosulfan II & 100.0 & 99.2 & 87.5 & 85.4 & 64.9 & 44.5 & 15.3 \\
\hline 4.4'DDT & 100.0 & 99.3 & 88.5 & 86.1 & 55.1 & 48.9 & 10.1 \\
\hline endrin aldehyde & 100.0 & 99.2 & 88.5 & 84.6 & 67.6 & 49.5 & 17.1 \\
\hline methoxychlor & 100.0 & 99.0 & 85.0 & 84.2 & 68.6 & 49.6 & 9.9 \\
\hline endrin sulfate & 100.0 & 99.4 & 86.9 & 84.4 & 66.5 & 50.9 & 8.9 \\
\hline endrin ketone & 100.0 & 99.3 & 87.0 & 84.3 & 54.6 & 46.3 & 15.3 \\
\hline$\%$ fat & 23.5 & 23.08 & 21.37 & 20.08 & 17.03 & 15.21 & 9.29 \\
\hline
\end{tabular}

M-Control; AFR-Cold smoking; AFC+PST-Warm smoking and pasteurization; PST+AFC-Pasteurization and warm smoking; FR-Frying; CO-Backing; IN-Stewing under pressure (cooking) M-AFR ${ }^{* * *}$ extremely significant $\mathrm{P} \leq 0.001$; M-(AFC+PST) ${ }^{* *}$ extremely significant $\mathrm{P} \leq 0.001$; M-(PST+AFC) ${ }^{* * *}$ extremely significant $\mathrm{P} \leq 0.001$; $M-F R^{* * *}$ extremely significant $\mathrm{P} \leq 0.001 ; \mathrm{M}-\mathrm{CO}^{* * *}$ extremely significant $\mathrm{P} \leq 0.001 ; \mathrm{M}-\mathrm{IN}$ not significant $\mathrm{P}>0.05$

Table 4: Head treatments efficiency applied to reduce organochlorine pesticides level in fortified pork neck samples. 
Citation: Muresan C, Covaci A, Socaci S, Suharoschi R, Tofana M, et al. (2015) Influence of Meat Processing on the Content of Organochlorine Pesticides. J Food Process Technol 6: 517. doi:10.4172/2157-7110.1000517
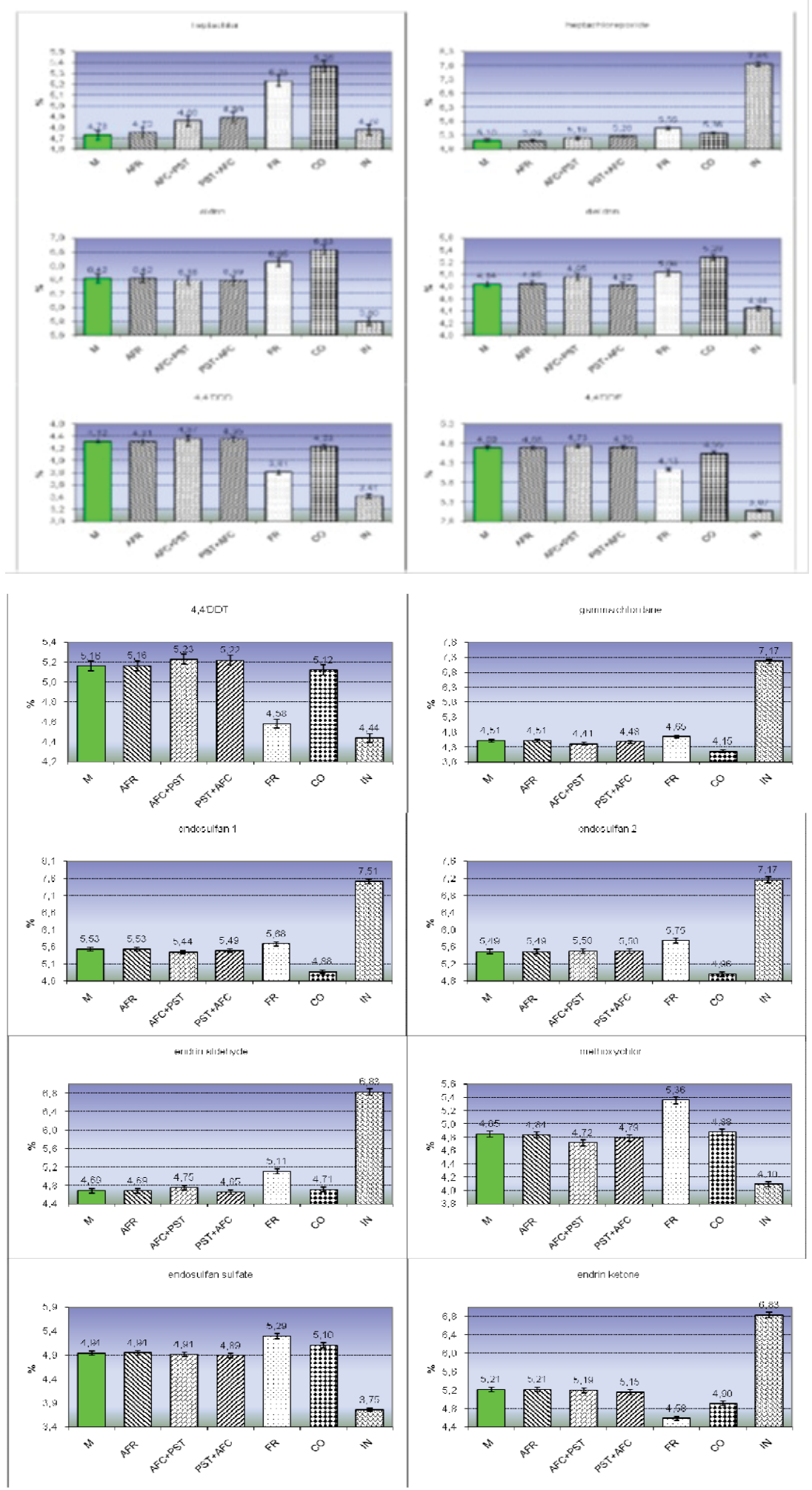

Figure 1: Evolution of OCPs weight in heat treatments applied (average fat content 23.5\%). M-Control: AFR- Cold smoking; AFC+PST-Warm smoking and pasteurization; PST+ AFC-Pasteurization and warm smoking; FR-Frying; CO-Backing; IN-Stewing under pressure (cooking). 
to the control sample (4.72\%). For this compound, the same trend was also noticed for cooking (5.36\%). One explanation could be the high resistance of heptachlor to thermal treatment as suggested in the literature (22).

Heptachlor epoxide has the same increase tendency compared to the control (5.09\%) regardless of the applied treatment, reaching a maximum level in the cooked sample (7.85\%). In the cold smoking treatment (AFR), the heptachlor epoxide concentration showed a slight increase (5.08\%) compared to the control sample. Perellò showed that the influence of cooking on organic pollutants depends not only on the cooking process, but also on the type of food. Aldrin reached a maximum share for cooking $(6.82 \%)$ and a minimum for baking $(5.8 \%)$ compared to a share of $6.41 \%$ in the control sample (M). Compared with to aldrin, the concentration of dieldrin was lower in the control sample (4.84\%), as well as in the cooked and baked samples (4.43 and $5.28 \%$, respectively). One explanation could be the possible oxidation of aldrin to dieldrin, as already reported in the literature $[10,22,23]$. The lowest levels of endrin aldehyde were determined for the pasteurization combined with the warm smoking treatment (4.65\%). Endosulfan I and II had the same trend compared to the control for the thermal treatments applied in this study. It may be noted that endosulfan I is more stable than endosulfan II during the studied thermal treatments. Clearly, the applied thermal treatments led to a partial elimination or degradation of OCPs. In particular, heptachlor and heptachlor epoxide appeared to be very resistant to the applied thermal treatments compared with dieldrin and DDT. Changes (degradation) can be chemically explained; for example, 4,4'-DDT is transformed to 4,4'-DDD through reductive dechlorination and to 4,4'-DDE through dehydrochlorination. Also, heptachlor can be oxidized to heptachlorepoxide [24,25].

In food products processed through frying, baking and stewing (home cooking), the reduction in the OCP content is higher compared to industrial processing of meat products (pasteurization, warm smoking, or cold smoking) $[7,13]$. The duration and temperature of the meat processing have both an important role in the fat degradation. In the baking and cooking processes, lipid hydrolysis can occur at temperatures above $100^{\circ} \mathrm{C}[15]$.

The advanced thermodegradation of fats is possible at high temperatures $\left(110,130\right.$, and $\left.180^{\circ} \mathrm{C}\right)$ and time periods $(0.5-1 \mathrm{~h})$ in processes, such as stewing, baking and frying [5]. During the thermal treatment, a break in the cells of the fat tissues takes place; the grease is removed and further dispersed into the meat mass. Depending on the meat processing, a part of the fat can be eliminated in the boiling mass (cooking or stewing) or removed through melting as it occurs in pasteurization, warm smoking and frying processes $[26,27]$

\section{Designing mathematical models to predict the effect of heat treatments on OCP levels in meat}

Table 5 presents the predictive mathematical models for all studied treatments. Statistical techniques are used in this study to model and predict, on a laboratory scale, the degree of reduction in the OCP

\begin{tabular}{|c|c|c|}
\hline Processing operation & $\mathbf{1}^{\text {st }}$ degree equation & RI \\
\hline Cold smoking (AFR) & $\mathrm{y}=0.992 \mathrm{x}+0.053$ & 0.9999 \\
\hline Warm smoking (AFC) & $\mathrm{y}=0.836 \mathrm{x}+5.102$ & 0.9959 \\
\hline Pasteurization (PST) & $\mathrm{y}=0.828 \mathrm{x}+3.277$ & 0.9975 \\
\hline Frying (FR) & $\mathrm{y}=0.464 \mathrm{x}+23.838$ & 0.8919 \\
\hline Baking (CO) & $\mathrm{y}=0.468 \mathrm{x}+2.586$ & 0.9532 \\
\hline Stewing under pressure (IN) & $\mathrm{y}=0.712 \mathrm{x}+3.539$ & 0.8875 \\
\hline
\end{tabular}

Table 5: Mathematical models of first degree equations for thermal treatments. content by controlling the limiting factors of the food processing treatments. This modelling aims to estimate the impact of an thermical process (cold smoking, smoking, warm smoking, pasteurization, frying, baking, and cooking) on the OCP content. The study used one control and 6 working variants, thus one variable set and their influence was studied. A prediction for the reduction degree in the contamination of meat samples subjected to 6 thermal treatments could be achieved. The coefficient of determination $\mathrm{r}^{2}$ indicates the response variation within the mathematical model, with values ranging between 0 and 1 . The $r^{2}$ value was found to be close to 1.0, which denotes a high correlation between the observed and predicted values. A higher value indicates a stronger relation between the studied variables $(x, y)$. The final value, $\mathrm{y}$, of OCP residues is function of the OCP residues, $\mathrm{x}$, before cooking treatments.

Cold smoking, warm smoking, pasteurization, and baking had $\mathrm{r}^{2}$ values close to 1 . For the stewing under pressure treatment, a predictive mathematical model could be developed only for some OCPs, namely for aldrin, 4,4'-DDD, 4,4'-DDT, methoxychlor and endosulfan sulfate. Statistical and mathematical techniques for designing experiments are useful tools to estimate the behavior of various compounds. Predictive mathematical models obtained from the experimental results depend on the behavior of the compounds analyzed. They can be thus used to choose the most appropriate thermal treatment method to reduce contamination. After applying various thermal treatments, the initial variation of OCPs from the original conditions is continuously modifying between treatments, being influenced by "intrinsic factors" linked to the physico-chemical properties of individual OCPs, such as: different partition coefficients between the lipidic and aqueous phase driven by differences in solubility; different volatility governed by different boiling points and by different stability of OCPs at high temperatures.

Our results show that the influence of cooking on the levels of OCPs in meat does not depend only on the particular cooking process, but even more on the specific food item. Lipophilic OCPs are associated with the fat portion of foods, thus cooking methods that release or remove fat from the product, will tend to reduce the total amount of OCPs in the cooked food. Dietary exposure to these environmental pollutants can be reduced by discarding the fat, which is released from foods during cooking $[14,16,17]$. Fortunately, this practice is already common among consumers who wish to reduce their fat intake.

\section{Acknowledgement}

Prof. Dr. Laslo Cornel, for the valuable help provided in the elaboration of the PhD thesis: Researches Concerning the Influence of Processing on organochlorine pesticide residues from meat and meat products.

\section{References}

1. Hura C, Leanca M, Rusu L, Hura BA (1999) Risk assessment of pollution with pesticides in food in the Eastern Romania area. Toxicol Lett 107: 103-107.

2. Witczak A (2012) Influence of smoking on indicatory PCB congeners residues levels in fish sliced. Pol. J Food Nutr Sci 62: 31-39.

3. Covaci A, Hura C, Schepens P (2001) Selected persistent organochlorine pollutants in Romania. Science of the Total Environment 280: 143-152.

4. Covaci A, Gheorghe A, Schepens P (2004) Distribution of organochlorine pesticides, polychlorinated biphenyls and a- $\mathrm{HCH}$ enantiomers in pork tissues. Chemosphere 56: 757-766.

5. Kubacki SJ, Lipowska T (1980) The role of food processing in decreasing pesticide contamination of foods. Food and Health: Science and Technology, Applied Science Publishers, London.

6. Gonzalez SM, Visweswariah K (1984) Efecto de la coccion sobre el 
Citation: Muresan C, Covaci A, Socaci S, Suharoschi R, Tofana M, et al. (2015) Influence of Meat Processing on the Content of Organochlorine Pesticides. J Food Process Technol 6: 517. doi:10.4172/2157-7110.1000517

contenidoresidual de hexaclorociclohexano $(\mathrm{BHC})$ en carrie de pollo broiler. Agricultura Tecnica 44: 39-43

7. Ariño A, Herrera MP, Conchello A, Perez C (1992) Hexachlorobenzene 282 residues in Spanish meat products after cooking, curing, and long term ripening. J Food Prot 55: 920-923

8. Conchello P, Herrera A, Ariño A, Lázaro R, Pérez-Arquillué C, et al. (1993) Effect of grilling, roasting, and cooking on the natural hexachlorobenzene content of ovine meat. Bull of Environmental Contamination and Toxicology 50: 828-833.

9. Rose M, Thorpe S, Kelly M, Harrison N, Startin J, et al. (2001) Changes in concentration of five PCDD/F congeners after cooking beef from treated cattle. Chemosphere 43: 861-868

10. Sengupta D, Aktar W, Alam S, Chowdhury A (2010) Impact assessment and decontamination of pesticides from meat under different culinary processes. Environ Monit Assess 169: 37-43

11. Rawn DFK, Breakell K, VSerigin V, Tittlemeir SA, Gobbo LD, et al. (2013) Impacts of Cooking Technique on Polychlorinated Biphenyl and Polychlorinated Dioxins/Furan Concentrations in Fish and Fish Products with Intake Estimates. J Agric Food Chem 61: 989-997.

12. Bayen S, Barlow P, Lee HK, Obbard JP (2005) Effect of cooking on the loss of persistent organic pollutants from salmon. Toxicology and environmental health 68: $253-265$

13. Domingo JL (2011) Influence of Cooking Processes on the Concentrations of Toxic Metals and Various Organic Environmental Pollutants in Food: A Review of the Published Literature. Critical reviews in Food Science and Nutrition 51: 29-37.

14. Hori T, Nakagawa R, Tobiishi K, lida T, Tsutsumi T, et al. (2005) Effects of cooking on concentrations of polychlorinated dibenzo-p-dioxins and related compounds in fish and meat. J Agric Food Chem 58: 8820-8828.

15. Mureşan C, Tofană M, Laslo C (2010) Effect of several technological and kitchen treatments on hexachlorocyclohexan residues in pork meat. Bulletin of the University of Agricultural Sciences and Veterinary Medicine Cluj-Napoca Agriculture 67: 312-318.

16. Perelló G, Martí-Cid R, Castell V, Llobet JM, Domingo JL, et al. (2009) Influence of various cooking processes on the concentrations of PCDD/Fs, PCBs and PCDEs in food. J Food Prot 21: 178-185.
17. Perelló G, Martí-Cid R, Llobet JM, Castell V, Domingo JL, et al. (2009) Concentrations of polybrominated diphenyl ethers, hexachlorobenzene and polycyclic aromatic hydrocarbons in various foodstuffs before and after cooking. Food and Chemical Toxicology 47: 709-715.

18. Liem AKD, Fürst $P$, Rappe $C$ (2000) Exposure of populations to dioxins and related compounds. Food Addit Contam 17: 241-259.

19. Zabik ME, Booren AL, Zabik MJ, Welch R, Humphrey H, et al. (1996) Pesticide residues, $\mathrm{PCB}$ and $\mathrm{PAHs}$ in baked, charbroiled, salt boiled and smoked Great Lakes lake trout. Food Chem 55: 231-239.

20. Zabik ME, Zabik MJ, Booren AM, Nettles M, Song JH, et al. (1995) Pesticides and total polychlorinated biphenyls in Chinook salmon and carp harvested from the Great Lakes: Effects of skin-on and skin-off processing and selected coking methods. J Agric Food Chem 43: 993-1001.

21. Katayama A, Matsumura F (1993) Degradation of organochlorine pesticides, particulary endosulfan, by Trichoderma harzianum. Environ Toxicol Chem 12 1059-1065.

22. Kipčić D, Vukušić J, Šebečić B (2001) Monitoring of chlorinated hydrocarbon pollution of meat and fish in Croatia. Food Technol Biotechnol 40: 39-47.

23. Morgan KJ, Zabik ME, Funk K (1972) Lindane, dieldrin and DDT residues 328 in raw and cooked chicken and chicken broth. Poultry Science 51: 470-475

24. Bai Y, Zhou L, Li J (2006) Organochlorine pesticide (HCH and DDT) residues in dietary products from Shaanxi province, People's Republic of China. Bull Environmental Contamination and Toxicology 76: 422-438.

25. Wilson ND, Shear NM, Paustenbach DJ, Price PS (1998) The effect of cooking practices on the concentration of DDT and $\mathrm{PCB}$ compounds in the edible tissue of fish. J Exp Anal Environ Epidemiol 8: 423-440.

26. Perello G, Marti-Cid R, Castell V, Llobetc JM, Domingoa JL, et al. (2010) Influence of various cooking processes on the concentrations of PCDD/PCDFs, PCBs and PCDEs in foods. Food Control 21: 178-185.

27. EC Regulation (2008) Regulation (EC) no. 299/2008 the European Parliament and of the Council amending Regulation (EC) no. 396/2005 on maximum residue levels of pesticides in or on food and feed. 